\title{
Molecular determination of antimicrobial resistance in Escherichia coli isolated from raw meat in Addis Ababa and Bishoftu, Ethiopia
}

Yohannes Equar Messele ${ }^{1 *}$, Reta Duguma Abdi ${ }^{2,3}$, Shimels Tikuye Yalew ${ }^{1}$, Desiye Tesfaye Tegegne ${ }^{1}$, Bezina Arega Emeru ${ }^{1}$ and Gebremeskel Mamu Werid ${ }^{1}$

\begin{abstract}
Background: Consumption of meat contaminated by E. coli causes a serious illness and even death to affected individuals. Recently the emerging of antibiotic resistant foodborne E. coli poses serious public health risks worldwide. However, little is known about the antibiotic resistance profile of E. coli in Ethiopia. This study aimed to determine the prevalence and Antimicrobial resistance (AMR) status of E. coli isolated from different type of meat.

Methods: Overall 292 samples were collected from December 2015 to April 2016 from slaughterhouses to determine the prevalence and AMR of E. coli isolated from raw beef, mutton, chevon and chicken meat from Addis Ababa and Bishoftu, Ethiopia. The isolates were screened for AMR against commonly used antibiotics circulating in the Ethiopian market. Both phenotypic and genotypic approach were employed for AMR detection using disc diffusion test and PCR respectively.

Results: The prevalence of E. coli was 63 (21.6\%), indicating one sample in every five samples harbors E. coli. Among these, the highest $E$. coli isolates was observed in chicken meat samples $(37.0 \% ; 27)$, followed by mutton $(23.3 \% ; 17)$, chevon $(20.6 \% ; 15)$ and beef $(5.5 \%$; 4$)$. Results of disk diffusion test on the 63 isolates showed that only $4.8 \%$ of them were not resistance to all antimicrobials tested. Multiple drug resistance (resistance to $\geq 3$ drugs) was $46.0 \%$. Significantly high resistance to ampicillin (71.4\%) and tetracycline (47.6\%) was observed. Identification of genes associated with AMR was also done using PCR. The prevalence of E. coli isolates harboring resistance gene responsible for tetracycline (tet(A)), beta lactams (blaCMY) and sulphanamide (sull) antibiotics were found 65.1, 65.1 and 54.0\%, respectively. Twenty-five out of the 63 (39.7\% \%) E. coli isolates have got antimicrobial resistance gene to three or more classes of drugs. The associations of antimicrobial resistance phenotypes and resistance genes was also determined. The detection of resistance trait against tetracycline, sulphametazole and chloramphenicol measured either phenotypically or genotypically were high.
\end{abstract}

Conclusions: The rising levels of resistance E. coli to multiple antimicrobial dictate the urgent need to regulate and monitor antimicrobial use in both animals and humans.

Keywords: Antibiotic resistance, Escherichia coli, Meat, Ethiopia

\footnotetext{
*Correspondence: equarachin@gmail.com

${ }^{1}$ Ethiopian Institute of Agricultural Research, National Agricultural

Biotechnology Research Center, P.O.Box 31, Holeta, Ethiopia

Full list of author information is available at the end of the article
} 


\section{Background}

Meat and meat products serve as important source of proteins for humans. However, recently the emerging antibiotic resistant foodborne pathogens combined with the injudicious use of antibiotics in animals bears considerate public health threats worldwide. Usually, meat and meat products gets contaminated by pathogens during animal slaughter and food processing. Escherichia coli (E. coli) is the frequently isolated foodborne pathogens from meat and meat products. Meat can be contaminated by $E$. coli during animal slaughter due to unhygienic slaughter practices, through airborne, rodents, insects, and other animals [1]. Consumption of meat contaminated by $E$. coli causes a serious illness and even death to affected individuals [2].

Recently published reports indicated that the E. coli strains isolated from contaminated meat and meat products have become resistant to commonly used antibiotics. This is mainly due to injudicious usage of antibiotics in both humans and animals [3]. The wide spread and imprudent use of antibiotics in food animals is thought to be accountable for the emergence and wider spreading of antimicrobial resistant (AMR) bacteria in humans [3, 4]. In humans, positive selection for drug resistant bacteria have also been reported in the normal microflora of exposed individuals or populations. This indicates that antibiotic resistance can be developed in both commensal and pathogenic bacterial strains and can even be transferred to other bacterial strains, including other pathogenic and environmental bacteria [5].

Consumption of contaminated and/or uncooked meat poses the risks of acquiring foodborne E. coli strains [6] causing a serious public health concern. These bacterial strains easily harbors antibiotic resistant genes from one another. This is because genes encoding AMR determinants that are carried on mobile genetic elements such as plasmids and transposons of some bacterial strains could be transferred to other bacteria strains during contact [7], causing a threat to cure acute infections in man and animals. In Ethiopia, a review done by Alemu et al. [8] showed that several pathogen have established resistance against oxytetracycline drugs. Similarly, oxytetracycline and penstrep are the main prescribed antibiotics in Ethiopia [8, 9]. So far, no study has been carried out to identify the antibiotic resistance genes of Escherichia coli in Ethiopia.

In this paper, we explain the phenotypic and genotypic sources of MDR in Escherichia coli isolates recovered from different type of meat samples taken from Addis Ababa city abattoir and Alema farm poultry slaughter slab, Ethiopia. This enquiry pursues to deliver useful evidence on the prevalence and AMR profile of E. coli isolated from beef, mutton, chevon and chicken meat.

\section{Methods}

Sample collection and isolation of $E$. coli

The study was carried out from December 2015 to April 2016 to collect meat sample from Addis Ababa city abattoir enterprise and Alema farm slaughter slab found in Bishoftu town, Ethiopia. A total of 292 meat sample including beef meat $(n=73)$, sheep meat $(n=73)$, goat meat $(n=73)$ were collected from Addis Ababa municipal abattoir and chicken meat $(\mathrm{n}=73)$ from Alema farm slaughter slab located in Bishoftu city. Sample were collected by swabbing from carcass gluteal muscle and inserted into $10 \mathrm{ml}$ peptone water containing test tube. The samples were taken following the guidelines of the International Organization for Standardization [10]. The sample were transported to National Agricultural Biotechnology Research Center in an ice box for further processing. The $E$. coli isolates were identified by using standard bacteriological methods, comprising of colony structure determination, using different culture media and biochemical tests as previously indicated [11]. Isolates were preserved at $-80{ }^{\circ} \mathrm{C}$ in a trypticase soy broth with $10 \%$ glycerol for further analysis.

\section{Antimicrobial susceptibility testing}

Antibiotic sensitivity was determined by disc diffusion method according to the guidelines of the Clinical and Laboratory Standards Institute [12]. Bacterial suspension was prepared by adding 2-4 colonies to a $5 \mathrm{ml}$ tube containing $0.9 \%$ normal saline $(\mathrm{NaCl})$, to achieve absorbance of $0.17-0.18$ at wavelength of $600 \mathrm{~nm}$ (equivalent to 0.5 McFarland standards) [13]. The suspension was spread onto Mueller-Hinton agar media (HIMEDIA, India) using a sterile cotton swab, and the antibiotic disc (Oxoid, UK) were placed on the top of the agar plate. The inoculated plates were incubated aerobically at $37{ }^{\circ} \mathrm{C}$ for 18-24 h, after which all E. coli isolates were tested for susceptibility using the following antimicrobial discs and their corresponding concentrations: tetracycline $(30 \mu \mathrm{g} /$ disk); streptomycin $(10 \mu \mathrm{g} /$ disk); chloramphenicol (30 $\mu \mathrm{g} /$ disk), sulfamethoxazole-trimethoprim (25 $\mu \mathrm{g} /$ disk), gentamycin $(10 \mu \mathrm{g} /$ disk); ampicillin, $(10 \mu \mathrm{g} /$ disk); erythromycin $(15 \mu \mathrm{g} /$ disk); by the Kirby-Bauer disk diffusion method [14].

\section{DNA extraction and PCR amplification of resistance genes}

Bacterial strains were grown overnight in nutrient agar (HIMEDIA, India) at $37^{\circ} \mathrm{C}$. A loop full of the colonies was added to $100 \mu \mathrm{l}$ of sterile water. Bacterial DNA was extracted by boiling a bacterial suspension in water. After boiling the suspension for $13 \mathrm{~min}$, the suspension were frozen for $5 \mathrm{~min}$ in ice and centrifuged at 14,000 rpm for $15 \mathrm{~min}$ to pellet the cell debris [15]. The supernatant from 
the centrifuged tubes was transferred to new $1.5 \mathrm{ml}$ clean plastic tube and used as a template for PCR amplification. The purified DNA were detected by electrophoresis in $1.5 \%$ agarose gel and then kept at $-20{ }^{\circ} \mathrm{C}$ for further use. Primers for AMR genes such as streptomycin (aadA1), tetracycline $[\operatorname{tet}(\mathrm{A})]$, gentamicin $[a a c(3)-I V]$, sulfonamides (sul1), beta-lactams (blaSHV, blaCMY), erythromycin $[\operatorname{ere}(\mathrm{A})]$ and chloramphenicol (catA1, cmlA) were used from published article. The specific primer sequences (Bioneer, South Korea) and the estimated size of the amplified products for different resistance gene coding regions are found in Table 1 . Amplification of antimicrobial resistance gene from $E$. coli isolates were performed as described by Fode et al. [16]. The amplification products were then separated by electrophoresis on a $1.5 \%$ agarose gel stained with gel red (Biotium Inc, USA) as described by Huang et al. [17] and visualized using UV illumination. A 100 bp DNA molecular marker (Bioneer, South Korea) were used to determine the size of the PCR product.

\section{Statistical analysis}

The prevalence of $E$. coli infection was quantified and compared among meat samples of different livestock species. Prevalence of AMR was quantified along with resistance patterns. The data were analyzed by using SPSS software version 20 and $P$ value was calculated using Chi square and Fisher's exact tests to determine any significant correlation. $\mathrm{P}$ value less than 0.05 was considered statistically significant.

\section{Results}

Prevalence of $E$. coli

In this study, a total of $63(21.6 \%)$ E. coli isolates were identified from the 292 raw meat samples examined (Table 2). Of these positive cases, chicken meat had the highest (37.0\%) whilst beef meat had the lowest prevalence $(5.5 \%)$ of $E$. coli. A significance difference in $E$. coli prevalence $(\mathrm{P}<0.05)$ was observed among meat samples of different livestock species. In this regard, meat of chevon 2.8 times, mutton 3.2 times and chicken meat

Table 1 Primers used for detection of antimicrobial resistant genes in Escherichia coli isolates

\begin{tabular}{|c|c|c|c|c|c|}
\hline Drug type & Antimicrobial resistance genes & Primers & Sequence $5^{\prime}-3^{\prime}$ & Amplicon size (Bp) & References \\
\hline \multirow[t]{2}{*}{ Streptomycin } & \multirow[t]{2}{*}{ Adenylyl transferases (aadA1) } & aadAlF & TATCCAGCTAAGCGCGAACT & \multirow[t]{2}{*}{447} & \multirow[t]{2}{*}[18]{} \\
\hline & & aadAlR & ATTTGCCGACTACCTTGGTC & & \\
\hline \multirow[t]{2}{*}{ Gentamicin } & \multirow[t]{2}{*}{ Aminoglycoside acetyltransferases (aac(3)-IV) } & $\operatorname{aac}(3)-I V F$ & CTTCAGGATGGCAAGTTGGT & \multirow[t]{2}{*}{286} & \\
\hline & & $\operatorname{aac}(3)-I V R$ & TCATCTCGTTCTCCGCTCAT & & \\
\hline \multirow[t]{2}{*}{ Sulfonamide } & \multirow[t]{2}{*}{ Dihydropteroate synthase (sul1) } & sultF & TTCGGCATTCTGAATCTCAC & \multirow[t]{2}{*}{822} & \\
\hline & & sultR & ATGATCTAACCCTCGGTCTC & & \\
\hline \multirow[t]{4}{*}{ Beta-lactams } & \multirow{2}{*}{$\begin{array}{l}\beta \text {-lactamase encoding penicillin resistance } \\
\left(b / a_{\mathrm{SHV}}\right)\end{array}$} & $b l a_{S H V} F$ & TCGCCTGTGTATTATCTCCC & \multirow[t]{2}{*}{768} & \\
\hline & & $b l a_{\mathrm{SHVR}}$ & CGCAGATAAATCACCACAATG & & \\
\hline & \multirow{2}{*}{$\begin{array}{l}\beta \text {-lactamase encoding cephalosporin resistance } \\
\left(b / a_{\mathrm{CMY}}\right)\end{array}$} & $b / a_{C M Y} F$ & TGGCCAGAACTGACAGGCAAA & \multirow[t]{2}{*}{462} & \\
\hline & & $b l a_{\mathrm{CMY}} \mathrm{R}$ & TTTCTCCTGAACGTGGCTGGC & & \\
\hline \multirow[t]{2}{*}{ Erythromycin } & \multirow[t]{2}{*}{ Erythromycin esterase (ere(A)) } & $\operatorname{ere}(\mathrm{A}) \mathrm{F}$ & GCCGGTGCTCATGAACTTGAG & \multirow[t]{2}{*}{419} & \\
\hline & & $\operatorname{ere}(A) R$ & CGACTCTATTCGATCAGAGGC & & \\
\hline \multirow[t]{4}{*}{ Chloramphenicol } & \multirow[t]{2}{*}{ Acetyltransferases (catA1) } & catAlF & AGTTGCTCAATGTACCTATAACC & \multirow{2}{*}{547} & \\
\hline & & catAlR & TTGTAATTCATTAAGCATTCTGCC & & \\
\hline & \multirow[t]{2}{*}{ Transporter resistance $(\mathrm{cm} / \mathrm{A})$} & $\mathrm{Cm} / \mathrm{AF}$ & CCGCCACGGTGTTGTTGTTATC & \multirow[t]{2}{*}{698} & \\
\hline & & $\mathrm{cm} / \mathrm{AR}$ & CACCTTGCCTGCCCATCATTAG & & \\
\hline \multirow[t]{2}{*}{ Tetracycline } & \multirow[t]{2}{*}{ Efflux pump resistance (tet(A)) } & $\operatorname{tet}(\mathrm{A}) \mathrm{F}$ & GGTTCACTCGAACGACGTCA & \multirow[t]{2}{*}{577} & \multirow[t]{2}{*}{ [19] } \\
\hline & & $\operatorname{tet}(\mathrm{A}) \mathrm{R}$ & CTGTCCGACAAGTTGCATGA & & \\
\hline
\end{tabular}

Table 2 Prevalence of $E$. coli in meat samples of different livestock species

\begin{tabular}{|c|c|c|c|c|c|}
\hline Meat sample & Total sample tested & No. of positives & Prevalence (\%) & OR & $P$ value \\
\hline Chicken & 73 & 27 & 37.0 & Reference & $<0.001$ \\
\hline Mutton & 73 & 17 & 23.3 & 0.51 & \\
\hline Chevon & 73 & 15 & 20.6 & 0.44 & \\
\hline Beef & 73 & 4 & 5.5 & 0.10 & \\
\hline Total & 292 & 63 & 21.6 & & \\
\hline
\end{tabular}


5.7 times were more infected than beef meat by $E$. coli indicating a difference in $E$. coli infection risk to humans based on meat type.

\section{Phenotypic antibiotic susceptibility test}

The distribution of Antimicrobial resistance (AMR) among the $E$. coli isolates from meat samples of four livestock species was shown in Table 3. The lists of AMR was Ampicillin (71.4\%), tetracycline (47.6\%), erythromycin (42.8\%), streptomycin (36.5\%), sulfamethoxazole-trimethoprim (34.9\%), chloramphenicol (23.8\%) and gentamycin (4.8\%). Among the E. coli isolates identified from meat of different food animals, resistance to ampicillin was highest in chevon (86.7\%), followed by chicken (70.4\%), mutton $(64.7 \%)$ and beef meat $(50 \%)$ as presented in Table 3.

Of 63 isolates, only 3 isolates (4.8\%) were pan-sensitive and the rest were single drug resistance (12 isolates; $20.4 \%)$, double drug resistance $(19 ; 30.2 \%)$ and multidrug ( $\geq 3$ or more drugs) resistance $(29 ; 46.0 \%)$. Two isolates demonstrated resistance to six different drugs. The AMR patterns and AMR frequencies were shown in Table 4. The most common AMR pattern found in the multiresistant isolates was ampicillin, tetracycline and erythromycin which jeopardizes the use of these drugs in the study area.

\section{Molecular detection of antimicrobial resistance}

All of the $63 \mathrm{E}$. coli isolates were confirmed by PCR to determine the existence of any AMR gene. The erythromycin esterase gene $\operatorname{ere}(A)$ and the aminoglycoside adenylyl transferases genes aadA1 were not identified in any of the $63 \mathrm{E}$. coli isolates (Fig. 1). The ere(A) gene confers resistance to erythromycin whilst aadA1 gene confer resistance to streptomycin. The most commonly detected AMR genes were blaCMY (65.1\%), tetA (65.1\%) and sul1 (54.0\%). The distribution of resistance genes among E. coli isolates are summarized in Table 5. The $b l a_{S H V}$, $\beta$-lactamase gene and $b l a_{C M Y}$ genes were identified in 4.8 and $65.1 \%$ of the isolates, respectively. The aac(3)$I V$ gene which codes resistance against gentamycin was found also in $14.3 \%$ of isolates.

Overall, 39.7\% (25/63) of isolates harbored resistance gene responsible to three or more drugs (Table 6). The most commonly detected genes were tetA, sul1, and $b l a_{C M Y}$. The most common pattern detected was sulI and tet $(A)$ together $(\mathrm{n}=23 ; 36.5 \%)$ followed by $b l a_{C M Y}$ and tet $A(\mathrm{n}=22 ; 35.0 \%)$ and $\mathrm{bla}_{\mathrm{CMY}}$ and $\operatorname{sulI}(\mathrm{n}=20 ; 31.7 \%)$.

\section{Relationship between drug resistance by disc diffusion and PCR methods}

The most commonly drugs to which isolates demonstrated resistance by disk diffusion method were

Table 3 Antimicrobial sensitivity test of $E$. coli isolates $(n=63)$ sampled from meat of different livestock species

\begin{tabular}{|c|c|c|c|c|c|c|c|}
\hline & $E$ & AMP & GN & $S$ & $\mathrm{TE}$ & Sxt & $\mathrm{C}$ \\
\hline \multicolumn{8}{|c|}{ Beef $(n=4)$} \\
\hline R (\%) & 0 & $2(50.0)$ & 0 & $2(50.0)$ & $2(50.0)$ & $1(25.0)$ & $1(25.0)$ \\
\hline I (\%) & $2(50.0)$ & $1(25.0)$ & 0 & $1(25.0)$ & 0 & 0 & $1(25.0)$ \\
\hline S (\%) & $2(50.0)$ & $1(25.0)$ & $4(100)$ & $1(25.0)$ & $2(50.0)$ & $3(75)$ & $2(50.0)$ \\
\hline \multicolumn{8}{|c|}{ Mutton $(n=17)$} \\
\hline R (\%) & $9(53.0)$ & $11(64.7)$ & $2(11.8)$ & $7(41.2)$ & $4(23.5)$ & $3(17.6)$ & $2(11.8)$ \\
\hline l (\%) & $7(41.2)$ & $3(17.6)$ & $1(5.9)$ & $3(17.6)$ & $2(11.8)$ & $3(17.6)$ & $3(17.6)$ \\
\hline S (\%) & $1(5.9)$ & $3(17.6)$ & $14(82.3)$ & $7(41.2)$ & $11(64.7)$ & $11(64.7)$ & $12(70.6)$ \\
\hline \multicolumn{8}{|c|}{ Chevon $(n=15)$} \\
\hline R (\%) & $7(46.7)$ & $13(86.7)$ & $1(6.7)$ & $1(6.7)$ & $3(20)$ & $1(6.7)$ & $1(6.7)$ \\
\hline l (\%) & $8(53.3)$ & 0 & $1(6.7)$ & $5(33.3)$ & $2(13.3)$ & $2(13.3)$ & 0 \\
\hline S (\%) & 0 & $2(13.3)$ & $13(86.7)$ & $9(60)$ & $10(66.7)$ & $12(80.0)$ & $14(93.3)$ \\
\hline \multicolumn{8}{|c|}{ Chicken $(n=27)$} \\
\hline R (\%) & $11(40.7)$ & $19(70.4)$ & 0 & $13(48.1)$ & $21(77.8)$ & $17(63.0)$ & $11(40.7)$ \\
\hline I (\%) & $10(37.0)$ & $3(11.1)$ & $7(26.0)$ & $6(22.2)$ & $4(14.8)$ & $3(11.0)$ & $5(18.5)$ \\
\hline S (\%) & $6(22.2)$ & $5(18.5)$ & $20(74.0)$ & $8(29.6)$ & $2(7.4)$ & $7(26.0)$ & $11(40.7)$ \\
\hline \multicolumn{8}{|l|}{ Overall } \\
\hline R (\%) & $27(42.9)$ & 45 (71.4) & $3(4.8)$ & $23(36.5)$ & $30(47.6)$ & $22(34.9)$ & $15(23.8)$ \\
\hline l (\%) & $27(42.9)$ & $7(11.1)$ & $9(14.3)$ & $15(23.8)$ & $8(12.7)$ & $8(12.7)$ & $9(14.3)$ \\
\hline S (\%) & $9(14.3)$ & $11(17.5)$ & $51(81.0)$ & $25(39.7)$ & $25(39.7)$ & $33(52.4)$ & $39(61.9)$ \\
\hline
\end{tabular}

$S$ sensitive, I intermediate, $R$ resistant, E erythromycin, AMP ampicillin, GN gentamycin, $S$ streptomycin, $T E$ tetracycline, Sxt sulfamethoxazole-trimethoprim, $C$ chloramphenicol 
Table 4 Antimicrobial resistance pattern of E. coli isolates from meat samples of different livestock species

\begin{tabular}{|c|c|c|}
\hline $\begin{array}{l}\text { Number of antibiotic } \\
\text { classes (number of iso- } \\
\text { lates; \%) }\end{array}$ & AMR pattern & Number of isolates (\%) \\
\hline No resistance & & $3(4.7)$ \\
\hline \multirow[t]{4}{*}{ One $(n=13 ; 20.6 \%)$} & AMP & $10(15.9)$ \\
\hline & E & $1(1.6)$ \\
\hline & TE & $1(1.6)$ \\
\hline & $C$ & $1(1.6)$ \\
\hline \multirow[t]{8}{*}{ Two $(n=19 ; 30.2 \%)$} & $\mathrm{AMP}^{*} \mathrm{C}$ & $1(1.6)$ \\
\hline & AMP*S & $1(1.6)$ \\
\hline & $A M P * S x t$ & $1(1.6)$ \\
\hline & AMP*TE & $4(6.3)$ \\
\hline & E*AMP & $6(9.5)$ \\
\hline & $E^{*} S$ & $1(1.6)$ \\
\hline & $E^{*} T E$ & $3(4.8)$ \\
\hline & $T E^{*} S x t$ & $1(1.6)$ \\
\hline \multirow[t]{7}{*}{ Three $(n=11 ; 17.5 \%)$} & $A M P * S x t^{*} C$ & $1(1.6)$ \\
\hline & $\mathrm{AMP}^{*} \mathrm{TE}^{*} \mathrm{C}$ & $1(1.6)$ \\
\hline & AMP*TE*Sxt & $3(4.8)$ \\
\hline & $E^{*} A M P * S$ & $1(1.6)$ \\
\hline & $E^{*} A M P * S x t$ & $1(1.6)$ \\
\hline & $\mathrm{S}^{*} \mathrm{~S} \times \mathrm{t}^{*} \mathrm{C}$ & $1(1.6)$ \\
\hline & $S^{*} T E * S x t$ & $3(4.8)$ \\
\hline \multirow[t]{6}{*}{ Four $(n=9 ; 14.3 \%)$} & $A M P^{*} S^{*} T E^{*} C$ & $1(1.6)$ \\
\hline & $A M P^{*} S^{*} T E^{*} S x t$ & $1(1.6)$ \\
\hline & $E^{*} A M P^{*} G N^{*} S$ & $3(4.8)$ \\
\hline & $E^{*} A M P^{*} S^{*} T E$ & $2(3.4)$ \\
\hline & $E^{*} A M P^{*} S x t^{*} C$ & $1(1.6)$ \\
\hline & $E^{*} A M P^{*} T E^{*} C$ & $1(1.6)$ \\
\hline \multirow[t]{3}{*}{ Five $(n=7 ; 11.1 \%)$} & $A M P^{*} S^{*} T E^{*} S x t^{*} C$ & $2(3.4)$ \\
\hline & $E^{*} A M P * S^{*} T E^{*} S x t$ & $2(3.4)$ \\
\hline & $E^{*} S^{*} T E^{*} S x t^{*} C$ & $3(4.8)$ \\
\hline $\operatorname{Six}(n=2 ; 3.2 \%)$ & $E^{*} A M P^{*} S^{*} T E^{*} S x t^{*} C$ & $2(3.4)$ \\
\hline
\end{tabular}

E erythromycin, $A M P$ ampicillin, $G N$ gentamicin, $S$ streptomycin, $T E$ tetracycline, Sxt sulfamethoxazole-trimethoprim, $C$ chloramphenicol

consistent with the most common resistance genes detected (Table 7). Tetracycline, sulfamethoxazole and chloramphenicol were top three drugs recognized as being the most common for resistance measured either disk diffusion or molecular method. However, the phenotypic and genotypic resistance characterization of the isolates to erythromycin, streptomycin and gentamycin were not correlated.

\section{Discussion}

The magnitude of $E$. coli prevalence and its AMR patterns were investigated in raw meat samples of four livestock species at Addis Ababa and Bishoftu slaughter house. In our study, in raw meat, the prevalence of $E$.

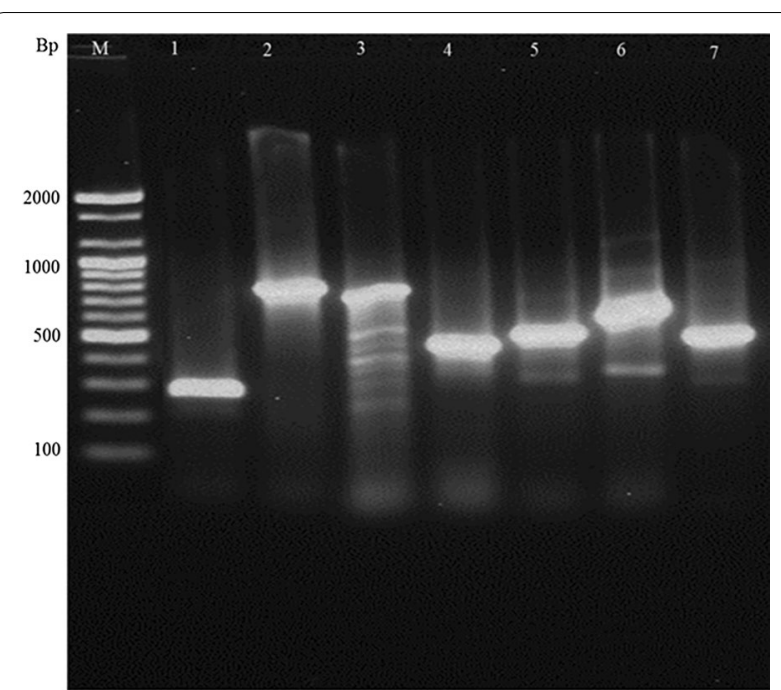

Fig. 1 PCR detection of E. coli AMR gene as visualized using agarose gel electrophoresis. Bp base pair, $M$ molecular weight standard, lane 1 aac(3)-IV (286 Bp), lane 2 sull (822 Bp), lane 3 bla SHV $_{\text {(768 Bp), lane } 4}$ bla $\mathrm{CMY}_{\mathrm{C}}(462 \mathrm{Bp})$, lane $5 \mathrm{catA} 1$ (547 Bp), lane $6 \mathrm{~cm} / \mathrm{A}$ (698 Bp), lane 7 tet(A) (577 Bp)

coli was $21.6 \%$. The study indicated that E. coli was 2.8 times, 3.2 times, and 5.7 times more prevalent in chevon, mutton and chicken meat, respectively, than in beef meat. It implies that meat of livestock species types has a difference in magnitude of $E$. coli infection, therefore, has implications on the risk to public health. It has been reported that poor hygienic practices is responsible for contamination of meat by E. coli [20]. The magnitude of E. coli prevalence in this study was similar to the previous studies in different part of Ethiopia 22.2, 26.6 and $20.3 \%$ by Haileselassie et al. [21], Haimanot et al. [22] and Bitew et al. [23] respectively. However, Mekonen et al. [24] and Taye et al. [25] also reported higher prevalence of carcass contamination with an overall isolation rate of 40 and $30.97 \%$, respectively. The current study deals with the magnitude of $E$. coli only at one point (i.e. slaughterhouse) of the food chain until it reaches the fork. It shouldn't be overlooked that there could be ample chances for $E$. coli to infect the meat released from the slaughterhouse during transport, handling and processing chains before it reaches the consumer (fork) as hygienic practices are substandard in Ethiopia. It has been reported that poor hygienic practices is responsible for contamination of meat by E. coli [20].

In the current study, the prevalence of $E$. coli was significantly higher in chicken meat than in chevon, mutton and beef meat. This might be attributed to husbandry and production systems where, small holder farmers prefer to rear their chickens in backyard to scavenge. Thus, $E$. coli could be transmitted from intestinal normal flora of 
Table 5 Distribution of AMR genes in E. coli isolates $(n=63)$ using PCR test

\begin{tabular}{|c|c|c|c|c|c|c|c|c|c|}
\hline \multirow[t]{2}{*}{ Meat type } & \multicolumn{9}{|c|}{ Number of isolates with AMR gene (\%) } \\
\hline & aadA1 & $\operatorname{aac}(3)-I V$ & sul1 & $b l a_{\mathrm{SHV}}$ & $b l a_{\mathrm{CMY}}$ & $\operatorname{ere}(\mathrm{A})$ & catA1 & $\mathrm{cm} / \mathrm{A}$ & $\operatorname{tet}(\mathrm{A})$ \\
\hline Beef $(n=4)$ & 0 & 0 & $1(25.0)$ & 0 & 0 & 0 & $1(25.0)$ & 0 & 0 \\
\hline Mutton $(n=17)$ & 0 & 0 & $5(29.4)$ & 0 & $11(64.7)$ & 0 & $1(5.9)$ & 0 & $11(64.7)$ \\
\hline Chevon $(n=15)$ & 0 & $1(6.7)$ & $9(60.0)$ & 0 & $14(93.3)$ & 0 & 0 & 0 & $5(33.3)$ \\
\hline Chicken $(n=27)$ & 0 & $8(29.6)$ & $19(70.4)$ & $3(11.1)$ & $16(59.2)$ & 0 & $3(11.1)$ & $7(26.0)$ & $25(92.6)$ \\
\hline Total & 0 & $9(14.3)$ & $34(54.0)$ & $3(4.8)$ & $41(65.1)$ & 0 & $5(8.0)$ & $7(11.1)$ & $41(65.1)$ \\
\hline
\end{tabular}

aadA1 streptomycin, aac(3)-IV gentamicin, sul1 sulfonamide, bla $a_{S H V}$ and $b l a_{C M Y}$ beta lactams, ere $(A)$ erythromycin, catA1 and $c m I A$ chloramphenicol, tet(A) tetracycline

livestock to the chicken via the food chain [26]. Over all, the variations observed among the reported prevalence could be emanated from difference in hygiene, breed, geographical origins of animals and history of treatment with antimicrobial.

Emergence and dissemination of antimicrobial resistance is on the increase trend among enteric bacteria [27]. In this research the overall result showed that significantly high resistance rate to ampicillin $(71.4 \%)$ and tetracycline $(47.6 \%)$. More importantly, in the current report, chicken meat harbored the highest number of drug resistant $E$. coli isolates compared to the other meat origins. As expected, the most common resistance were found to older drugs such as ampicillin (Introduced in 1961) followed by tetracycline (Introduced in 1948) [28]. Similarly, Momtaz et al. [29] observed that tetracycline, sulfamethoxazole, chloramphenicol and trimethoprim resistance was the most common finding with the prevalence rate of 91.2, 45.6 and $29.8 \%$ respectively. Likewise, studies conducted in Korem, Ethiopia on diarrheic patients showed that the highest E. coli resistance were found against ampicillin followed by chloramphenicol, and tetracycline [30]. Hiko et al. [31] also found that the isolated E. coli is highly resistant to streptomycin, cephlaothin, tetracycline, ampicillin and trimethoprim. Another study revealed that all $E$. coli isolates from beef were found $100 \%$ resistance to ampicillin and amoxicillin and 33.33\% to tetracycline [25]. The observed higher level of antimicrobial resistance might be attributed to the widespread and indiscriminate use of antibiotics in animals for medication and other prophylaxis purposes. Although tetracycline has the second most resistance in this study, it is one of the most commonly used antibiotics for the treatment of different infections, including $E$. coli in Ethiopia.

Recently, among gram negative bacteria, multidrug resistant (MDR) phenotypes are spreading widely [32]. In the current study, the overall rate of multiple drug resistance was $46.0 \%$ and only $4.8 \%$ of the isolates were found sensitive to all antimicrobials tested (Table 4). This is in agreement with the findings of Schroeder et al. [33]
Table 6 Multiple antimicrobial resistance gene patterns of $E$. coli isolates

\begin{tabular}{|c|c|c|}
\hline $\begin{array}{l}\text { Number of AMR gene } \\
\text { (\%) }\end{array}$ & $\begin{array}{l}\text { Resistance gene } \\
\text { patterns }\end{array}$ & $\begin{array}{l}\text { Number of isolates } \\
\text { (\%) }\end{array}$ \\
\hline \multicolumn{2}{|l|}{ No resistance } & $7(11.1)$ \\
\hline \multirow[t]{4}{*}{ One $(\mathrm{n}=11 ; 17.5 \%)$} & $b l a_{\mathrm{CMY}}$ & $6(9.5)$ \\
\hline & tet(A) & $3(4.7)$ \\
\hline & sul1 & $1(1.6)$ \\
\hline & catA1 & $1(1.6)$ \\
\hline \multirow[t]{7}{*}{ Two $(n=20 ; 31.8 \%)$} & $a a c(3)-I V^{*} b l a_{C M Y}$ & $1(1.6)$ \\
\hline & $\operatorname{aac}(3)-I V^{*} \operatorname{tet}(\mathrm{A})$ & $1(1.6)$ \\
\hline & $\mathrm{cm} / \mathrm{A}^{*} \operatorname{tet}(\mathrm{A})$ & $1(1.6)$ \\
\hline & $b l a_{\mathrm{CMY}} * \operatorname{tet}(\mathrm{A})$ & $7(11.1)$ \\
\hline & sul1* bla ${ }_{\mathrm{CMY}}$ & $5(7.9)$ \\
\hline & sul1* catA1 & $1(1.6)$ \\
\hline & $\operatorname{sul} 1^{*} \operatorname{tet}(\mathrm{A})$ & $4(6.3)$ \\
\hline \multirow[t]{5}{*}{ Three $(n=15 ; 23.8 \%)$} & $\operatorname{sull}^{*} b a_{\mathrm{CMY}}{ }^{*} \operatorname{tet}(\mathrm{A})$ & $10(15.9)$ \\
\hline & $\operatorname{sul} 1^{*} \mathrm{~cm} / A^{*} \operatorname{tet}(\mathrm{A})$ & $2(3.2)$ \\
\hline & $\operatorname{aac}(3)-I V^{*} \operatorname{sul} 1^{*} \operatorname{tet}(\mathrm{A})$ & $1(1.6)$ \\
\hline & $b l a_{\mathrm{CMY}} * \mathrm{~cm} / A^{*} \operatorname{tet}(\mathrm{A})$ & $1(1.6)$ \\
\hline & $b l a_{\mathrm{CMY}}{ }^{*} \operatorname{cat} A 1^{*} \operatorname{tet}(\mathrm{A})$ & $1(1.6)$ \\
\hline \multirow[t]{4}{*}{ Four $(n=6 ; 9.5 \%)$} & $\begin{array}{l}\operatorname{sul}_{1 *}^{*} b a_{\mathrm{CMY}}{ }^{*} \operatorname{cat} A 1^{*} \\
\operatorname{tet}(\mathrm{A})\end{array}$ & $2(3.2)$ \\
\hline & $\begin{array}{l}\operatorname{aac}(3)-I V^{*} \operatorname{sul} 1^{*} b l a_{\mathrm{CMY}} \\
{ }^{*} \operatorname{tet}(\mathrm{A})\end{array}$ & $2(3.2)$ \\
\hline & $\begin{array}{l}\operatorname{sul}^{*}{ }^{*} b a_{\mathrm{CMY}}{ }^{*} \mathrm{~cm} / A^{*} \\
\operatorname{tet}(\mathrm{A})\end{array}$ & $1(1.6)$ \\
\hline & $\begin{array}{l}\text { sul1 } * b / a_{\mathrm{SHV}} * b / a_{\mathrm{CMY}} \\
{ }^{*} \operatorname{tet}(\mathrm{A})\end{array}$ & $1(1.6)$ \\
\hline \multirow[t]{2}{*}{ Five $(n=4 ; 6.3 \%)$} & $\begin{array}{l}\operatorname{aac}(3)-I V^{*} \operatorname{sul} / 1^{*} b l a_{\mathrm{CMY}} \\
{ }^{*} \mathrm{~cm} / A^{*} \operatorname{tet}(\mathrm{A})\end{array}$ & $2(3.2)$ \\
\hline & $\begin{array}{l}a a c(3)-I V^{*} \operatorname{sul} 1^{*} b l a_{\mathrm{SHV}} \\
{ }^{*} \operatorname{bla}_{\mathrm{CMY}}{ }^{*} \operatorname{tet}(\mathrm{A})\end{array}$ & $2(3.2)$ \\
\hline
\end{tabular}

aadA1 streptomycin, aac(3)-IV gentamicin, sul1 sulfonamide, $b / a_{S H V}$ and $b l a_{C M Y}$ beta lactams, ere(A) erythromycin, cat $A 1$ and $\mathrm{cm} / A$ chloramphenicol, tet( $(A)$ tetracycline

and Zhao et al. [34] from USA that reported that multiple resistance to tetracycline, kanamycin, streptomycin, ampicillin, and sulfamethoxazole. Similarly, among sulfonamide resistant $E$. coli isolates, Wu et al. [35] reported that ampicillin and streptomycin are the two 
Table 7 Agreement between the two tests on resistance isolate detection from the 63 isolates tested

\begin{tabular}{lll}
\hline Antimicrobial resistance isolates (\%) & Resistance gene detected (\%) & Agreement (\%) \\
\hline Erythromycin $(n=27 ; 42.8)$ & $\operatorname{ere}(A)(n=0)$ & 0 \\
Gentamicin $(n=3 ; 4.8)$ & $\operatorname{aac}(3)-\operatorname{IV}(n=9 ; 14.3)$ & 0 \\
Streptomycin $(n=23 ; 36.5)$ & $\operatorname{aadAl}(n=0)$ & 0 \\
Tetracycline $(n=30 ; 47.6)$ & $\operatorname{tet}(A)(n=41 ; 65.1)$ & $23(76.7)$ \\
Sulfamethoxazole-trimethoprim $(n=22 ; 34.9)$ & $\operatorname{sul}(n=34 ; 54.0)$ & $14(63.6)$ \\
Chloramphenicol $(n=15 ; 23.8)$ & $\operatorname{catAl}(n=5 ; 8.0)$ & $2(13.3)$ \\
& $\operatorname{cm} / A(n=7 ; 11.1)$ & $4(26.7)$ \\
\hline
\end{tabular}

most frequently co-transferred resistance phenotypes. However, Daniel et al. [28] reported a resistance profile of tetracycline $(80 \%)$ and streptomycin (74\%), among the sulfonamide-resistant $E$. coli isolates. The transfer of resistance among microorganisms has long been recognized as a serious threat, contributing to the evolution and emergence of antibiotic resistant bacteria, thereby reducing the therapeutic potential against pathogens [36].

After phenotypic screening, genes associated with antimicrobial resistance was analyzed using PCR. In this study, the most commonly detected resistance genes were blaCMY (65.1\%), tetA (65.1\%) and sul1 (54.0\%)) for cephalosporin, tetracycline and sulfonamide respectively. However, streptomycin and erythromycin resistance genes were not detected. In Iran, among the E. coli isolates, $52.6 \%$ of resistance to tetracycline as well as $47.4 \%$ for both sulfonamides and erythromycin was reported [31]. The prevalence of different resistance genes from pediatric patient $E$. coli isolate were also reported 85.06, $60.38,57.79,90.25,40.25$ and $54.54 \%$ positive for tet $A$, cmlA, SHV $\beta$-lactamase, CITM, sul1 and aac(3)-IV resistance genes respectively [37].

The phenotypic and genotypic resistance patterns with in the same E. coli isolates might be strongly correlated [38]. In our research, detection of tetracycline resistance by disk diffusion test and identification of its resistance gene tet $(A)$ by PCR test, sulfamethoxozole-trimethoprim and sull, chloramphenicol and $c m l A$ were strongly associated. But there was a lack of association between phenotypic erythromycin resistance and molecular detection of $\operatorname{ere}(A)$, streptomycin and aadA1, chloramphenicol and catA1 resistance gene. Similarly, reports from Thailand showed that, E. coli isolates from chickens were found to be resistant to tetracycline (90\%) and erythromycin (73.3\%) in Agar disk diffusion assays and these resistance properties were associated with $\operatorname{tet}(\mathrm{A})$ and $\operatorname{ere}(\mathrm{A})$ resistance genes respectively [4]. However, the presence of resistance phenotypes might not represent all the underlying resistance genes. Alternatively, the presence or absence of a resistance gene might not indicate the particular isolate is resistant or susceptible to an antimicrobial [39].

The observed discrepancy in the resistance level of genotypes and phenotypes might be attributed to either of or combination of the reasons including but not limited to the presence of unexpressed genes in the bacterial isolates, not containing the possible resistance genes in the test, use of incorrect cut points of test results used for resistance and susceptibility classification, or some of resistance phenotypes are caused by due to point mutations rather than gene transfer or acquisition [40].

\section{Conclusions}

This study revealed that raw meat available for consumers in Ethiopia was often contaminated with E. coli. We reported on a comprehensive study of the phenotypic and molecular basis for Multi Drug Resistance (MDR) in meat E. coli isolates recovered from Ethiopian Abattoir. Furthermore, a high rate of resistance to Ampicillin and resistance to more than one class of antibiotics among $E$. coli isolates was found. Additionally, several strains were found positive for the $b l a_{\mathrm{CMY}}$, tet $(A)$, and sul1 antimicrobial resistance genes. All these findings suggest that the consumption of undercooked meat or food cross-contaminated with $E$. coli may pose a serious threat to consumer health.

\section{Abbreviations}

AMR: antimicrobial resistance; MDR: multidrug resistance; aadA1: streptomycin resistance gene; tet(A): tetracycline resistance gene; aac(3)-IV: gentamycin resistance gene; sull: sulphanamide resistance gene; blaSHV: betalactam resistance gene (pencillin); blaCMY: betalactam resistance gene (cephalosporin); ere(A): erythromycin resistance gene; catA1: chloramphenicol resistance gene; $\mathrm{cm} / A$ : chloramphenicol resistance gene; PCR: polymerase chain reaction; $\mathrm{MgCl}_{2}$ : magnesium chloride; dNTP: deoxynucleotide tri phosphate; UV: ultra violet; Bp: base pair; OR: odds ratio; DNA: deoxynucleic acid; SPSS: statistical package for social science; $X 2$ : Pearson chi square; $P$ value: predictive value; $R$ : resistance; I: intermediate; S: susceptible; E: erythromycin; Amp: ampicillin; GN: gentamycin; S: streptomycin; TE: tetracycline; Sxt: sulfamethoxazole-trimethoprim; C: chloramphenicol; ISO: International Organization for Standardization; CLIS: Clinical and Laboratory Standards Institute. 


\section{Authors' contributions}

The research idea and study design was developed by YEM and GMW. Sample collection were done by YEM, STY, DTT and BAE. YEM supervised the study. YEM and RDA provided valuable information on data analysis and manuscript writing. All authors read and approved the final manuscript.

\section{Author details}

${ }^{1}$ Ethiopian Institute of Agricultural Research, National Agricultural Biotechnology Research Center, P.O.Box 31, Holeta, Ethiopia. ${ }^{2}$ College of Veterinary Medicine and Agriculture, Addis Ababa University, P.O.Box 34, Bishoftu, Ethiopia. ${ }^{3}$ University of Tennessee Institute of Agriculture Department of Animal Science, Rivers Drive, Knoxville, TN, USA.

\section{Acknowledgements}

I greatly appreciate the contribution made by the Ethiopian National Agricultural Biotechnology Research Center in funding this project and the staff of the Animal Biotechnology Laboratory, for assisting during the bench work which has led to the success of this work.

\section{Competing interests}

The authors declare that they have no competing interests.

\section{Availability of data and materials}

The datasets used and/or analyzed during the current study are available from the corresponding author on reasonable request.

\section{Consent to publish}

Not applicable.

\section{Ethics and consent to participate}

Not applicable.

\section{Publisher's Note}

Springer Nature remains neutral with regard to jurisdictional claims in published maps and institutional affiliations.

Received: 14 October 2016 Accepted: 9 August 2017

Published online: 15 August 2017

\section{References}

1. Laury A, Echeverry A, Brashears M. Fate of Escherichia coli O157:H7 in meat Chapter 2. In: Toldra F, editor. Safety of meat and processed meat. New York: Springer; 2009. p. 31-53.

2. Pradel N, Livrelli V, De Champs C, Palcoux JB, Reynaud A, Scheutz F, et al. Prevalence and characterization of Shiga toxin producing Escherichia coli isolated from cattle, food, and children during a one-year prospective study in France. J Clin Microbiol. 2000;38:1023-31.

3. Molbak K. Spread of resistant bacteria and resistance genes from animals to humans, the public health consequences. J Vet Med. 2004:51:364-9.

4. Mooljuntee S, Chansiripornchai P, Chansiripornchai N. Prevalence of the cellular and molecular antimicrobial resistance against E. coli isolated from Thai broilers. Thai J Vet Med. 2010;40:311-5.

5. Lindsey RL, Frye SN, Thitaram RJ, Meinersmann PJ. Fedorka-Cray, Englen MD. Characterization of multidrug-resistant Escherichia coli by antimicrobial resistance profiles, plasmid replicon typing, and pulsed-field gel electrophoresis. Microb Drug Resist. 2011;17:157-63.

6. Frye JG, Jackson CR. Genetic mechanisms of antimicrobial resistance identified in Salmonella enterica, Escherichia coli, and Enterococcus spp. Isolated from U.S. food animals. Front Microbiol. 2013;4:135.

7. Van den Bogaard AE, Stobberingh EE. Epidemiology of resistance to antibiotics. Links between animals and humans. Int J Antimicrob Agents. 2000; 14:327-35

8. Alemu T, Eyasu M, Solomon G, Tenaw A, Yilkal A. Literature review on infectious diseases, antimicrobial use, resistance and containment. In: Antimicrobial use, resistance, and containment baseline survey syntheses of findings. Drug administration and control authority of ethiopia in collaboration with management sciences for health, strengthening pharmaceutical systems; 2009. p. 37-42.

9. Beyene T, Endalamaw D, Tolossa Y, Feyisa A. Evaluation of rational use of veterinary drugs especially antimicrobials and anthelmintics in Bishoiu, Central Ethiopia. BMC Res Notes. 2015:8:482.

10. International Organization for Standardization (ISO). Microbiology of food and animal feeding stuffs carcass sampling for microbiological analysis. Geneva: International Organization for Standardization; 2013.

11. Hitchins AD, Feng P, Watkins WD, Rippey SR, Chandler LA. Escherichia coli and the coliform bacteria. In: U.S. Food and Drug Administration, editor. Bacteriological analytical manual. Gaithersburg: AOAC International; 1998. p. 401-29.

12. Clinical and Laboratory Standards Institute (CLIS). Performance standards for antimicrobial susceptibility testing; twenty-second informational supplement. Wayne: M100-S21, CLS; 2012

13. Walker RD. Antimicrobial susceptibility testing and interpretation of results. Antimicrobial therapy in veterinary medicine. Ames: RD Walker lowa State Press, 2000. p. 12-26.

14. Bauer A, Kirby W, Sherris J, Turck M. Antibiotic susceptibility testing by a standardized single disk method. Am J Clin Pathol. 1966;45(4):493-6.

15. Reischl U, Youssef M, Kilwinski J, Lehn N, Zhang W, Karch H, et al. Realtime fluorescence PCR assays for detection and characterization of Shiga toxin, intimin, and enterohemolysin genes from Shiga toxin-producing Escherichia coli. J Clin Microbiol. 2002;40:2555-65.

16. Fode-Vaughan K, Maki J, Benson J, Collins M. Direct PCR detection of Escherichia coli O157:H7. Lett Appl Microbiol. 2003;37:239-43.

17. Huang Q, Baum L, Fu W. Simple and practical staining of DNA with gel red in agarose gel electrophoresis. Clin Lab. 2010;56(3-4):149-52.

18. Van TT, Chin J, Chapman T, Tran LT, Coloe PJ. Safety of raw meat and shellfish in Vietnam: an analysis of Escherichia coli isolations for antibiotic resistance and virulence genes. Int J Food Microbiol. 2008;124:217-23.

19. Randall LP, Cooles SW, Osborn MK, Piddock LJ, Woodward MJ. Antibiotic resistance genes, integrons and multiple antibiotic resistance in thirtyfive serotypes of Salmonella enterica isolated from humans and animals in the UK. J Antimicrob Chemother. 2004;53:208-16.

20. Vahedi M, Nasrolahei M, Sharif M, Mirabi A. Bacteriological study of raw and unexpired pasteurized cow's milk collected at the dairy farms and super markets in Sari City in 2011. J Prev Med Hyg. 2013;54:120-3.

21. Haileselassie M, Taddele H, Adhana K. Source(s) of contamination of 'raw' and 'ready-to-eat' foods and their public health risks in Mekelle City, Ethiopia. J Food Agric Sci. 2012;2(2):20-9.

22. Haimanot $T$, Alemseged A, Getnet B, Solomon G. Microbial flora and food borne pathogens on minced meat and their susceptibility to antimicrobial agents. Ethiop J Health Sci. 2010;20(3):137-43.

23. Bitew M, Tafere A, Tolosa T. Study on bovine mastitis in dairy farms of Bahir Dar town and its environment. J Anim Vet Adv. 2010;9:2912-7.

24. Mekonnen H, Habtamu T, Kelali A, Shewit K. Food safety knowledge and practices of abattoir and butchery shops and the microbial profile of meat in Mekelle city, Ethiopia. Asian Pac J Trop Biomed. 2013;3(5):407-12.

25. Taye M, Berhanu T, Berhanu Y, Tamiru F, Terefe D. Study on carcass contaminating Escherichia coli in apparently healthy slaughtered cattle in Haramaya University slaughter house with special emphasis on Escherichia coli O157:H7, Ethiopia. J Vet Sci Technol. 2013;4:132.

26. Ming-Cheng L, Fang W, Fan L. Identification and molecular characterization of antimicrobial-resistant shiga toxin-producing Escherichia coli isolated from retail meat products. Foodborne Pathog Dis. 2011;8(4):489-93.

27. Sawant AA, Hegde NV, Straley BA, Donaldson SC, Love BC, Knabel SJ, et al. Antimicrobial-resistant enteric bacteria from dairy cattle. Appl Environ Microbiol. 2007;73:156-63.

28. Daniel A, Shaohua Z, Emily T, Sherry A, Aparna S, Mary J, et al. Antimicrobial drug resistance in Escherichia coli from humans and food animals, united states, 1950-2002. Emer Infect Dis. 2012;18(5):741-9.

29. Momtaz H, Rahimi E, Moshkelani S. Molecular detection of antimicrobial resistance genes in E. coli isolated from slaughtered commercial chickens in Iran. Vet Med. 2012;57(4):193-7.

30. Meng J, Zhao S, Doyle M, Joseph S. Antibiotic resistance of Escherichia coli 0157:H7 and 0157: NM isolated from animals, food, and humans. J Food Prot. 1998:61:1511-4.

31. Hiko A, Daniel A, Girma Z. Occurrence of Escherichia coli O157:H7 in retail raw meat products in Ethiopia. Infect Dev Ctries. 2008;2(5):389-93. 
32. Higgins CF. Multiple molecular mechanisms for multidrug resistance transporters. Nature. 2007;446:749-57.

33. Schroeder CM, Zhao C, DebRoy C, Torcolini J, Zhao S, White DG, et al. Antimicrobial resistance of Escherichia coli 0157 isolated from humans, cattle, swine, and food antimicrobial resistance of Escherichia coli $\mathrm{O} 157$ isolated from humans, cattle, swine, and food. Appl Environ Microbiol. 2002;68:576-81.

34. Zhao S, White DG, Ge B, Ayers S, Friedman S, English L, et al. Identification and characterization of integron mediated antibiotic resistance among shiga toxin-producing Escherichia coli isolates. Appl Environ Microbiol. 2001;67:1558-64

35. Wu S, Dalsgaard A, Hammerum A, Porsbo L, Jensen L. Prevalence and characterization of plasmids carrying sulfonamide resistance genes among Escherichia coli from pigs, pig carcasses and human. Acta Vet Scand. 2010;52:47.
36. Hawkey P, Jones A. The changing epidemiology of resistance. J Antimicrobial Chemother Suppl. 2009;1:3-10.

37. Maryam H, Hassan M, Mahboobeh M. Characterization of diarrheagenic antimicrobial resistant Escherichia coli isolated from pediatric patients in Tehran, Iran. Red Crescent Med J. 2014;16(4):e12329.

38. Shaw K, Hare R, Sabatelli F, Rizzo M, Cramer C, Naples L, et al. Correlation between aminoglycoside resistance profiles and DNA hybridization of clinical isolates. Antimicrob Agents Chemother. 1991;35:2253-61.

39. Aarts, H, Guerra B, Malorny B. Molecular methods for detection of antimicrobial resistance in antimicrobial resistance in bacteria of animal origin $\mathrm{F}$. Aarestrup M, editor. Washington DC: ASM press; 2006. p. 37-48.

40. Blake D, Humphry R, Scott K, Hillman K, Fenlon D, Low J. Influence of tetracycline exposure on tetracycline resistance and the carriage of tetracycline resistance genes within commensal Escherichia coli populations. J App Microbiol. 2003;94:1087-97.

\section{Submit your next manuscript to BioMed Central and we will help you at every step:}

- We accept pre-submission inquiries

- Our selector tool helps you to find the most relevant journal

- We provide round the clock customer support

- Convenient online submission

- Thorough peer review

- Inclusion in PubMed and all major indexing services

- Maximum visibility for your research

Submit your manuscript at www.biomedcentral.com/submit 